\title{
Humanising the Energy Transition: Towards a National Policy on Energy Poverty in the Netherlands
}

\author{
Mariëlle Feenstra ${ }^{1 *}$, Lucie Middlemiss ${ }^{2}$, Marlies Hesselman ${ }^{3}$, Koen Straver $^{4}$ and \\ Sergio Tirado Herrero ${ }^{5}$
}

${ }^{1}$ Department of Governance and Technology for Sustainability (CSTM), University of Twente, Enschede, Netherlands, ${ }^{2}$ Sustainability Research Institute, University of Leeds, Leeds, United Kingdom, ${ }^{3}$ Faculty of Law, University of Groningen, Groningen, Netherlands, ${ }^{4}$ TNO Netherlands Organisation for Applied Scientific Research, Amsterdam, Netherlands, ${ }^{5}$ Institute of Environmental Science and Technology, Universitat Autònoma de Barcelona, Barcelona, Spain

OPEN ACCESS

Edited by:

Neil Simcock,

Liverpool John Moores University,

United Kingdom

Reviewed by:

Paul McKenzie,

Ulster University, United Kingdom

Dana Abi Ghanem,

Teesside University, United Kingdom

*Correspondence:

Mariëlle Feenstra

m.h.feenstra@utwente.nl

Specialty section:

This article was submitted to

Urban Energy End-Use,

a section of the journal

Frontiers in Sustainable Cities

Received: 23 December 2020 Accepted: 29 April 2021

Published: 01 June 2021

Citation:

Feenstra M, Middlemiss L, Hesselman M, Straver K and Tirado Herrero S (2021) Humanising the Energy Transition: Towards a National

Policy on Energy Poverty in the Netherlands.

Front. Sustain. Cities 3:645624. doi: 10.3389/frsc.2021.645624
Energy poverty is emerging as a national agenda in the Netherlands. Local authority leadership and action on this agenda, and European Union reporting requirements around the energy transition have aligned to create an opportunity to establish a national agenda on this issue. Early action on energy poverty by local authorities stemmed from their recognition of the value of addressing environmental, health, social welfare and poverty goals through measures to address the problem. In contrast, the experiences of vulnerable energy consumers have limited recognition in national policy. Meanwhile EU requirements for climate reporting include a specification for measuring and monitoring energy poverty. This growing momentum has resulted in an emerging interest in energy poverty as a means to achieve a just transition at a national level, as reflected in the Dutch National Climate and Energy Plan. In this paper, we profile the case of the Netherlands, and outline the opportunity we see for the development of an energy poverty agenda in national energy transition policy, as part of a multi-level energy governance effort. We report on a national stakeholder workshop that we led, linking the lived experience of energy poverty in the Netherlands with policy solutions. Following the clear call for a national policy in this workshop, we also outline a strategy for engagement with energy poverty in the Netherlands, published recently in a white paper on this topic.

Keywords: energy poverty, energy justice, energy transition, energy governance, the Netherlands

\section{INTRODUCTION}

In this paper we profile the case of the Netherlands, and outline the opportunity we see for the inclusion of the energy poverty agenda in the national energy transition policy as part of a multi-level governance process that includes municipalities and the EU level in driving forward new national policy, indicators and measures on energy poverty. Energy poverty is only an emerging agenda in the Netherlands, principally driven by local authorities' recognition of the value of addressing environmental, health, social welfare and poverty goals through measures to address the problem, and European Union (EU) requirements for reporting on energy poverty as part of the Energy Transition. There is, as yet, no national policy, and the national government has been reluctant to articulate energy poverty as distinct from poverty in general. This creates challenges at a local level, where local authority and regional action is inconsistent, and suffers from the lack of a national framework in accessing funds and developing activities. Even if reluctantly, the recent 
Dutch National Climate and Energy Plan (NECP) approved in November 2019 touches on energy poverty, particularly in relation to its contribution to a just energy transition. This has created an opportunity for a national policy on energy poverty, which links strongly with policy on energy transition.

This paper was inspired by a process of engagement that we led in 2019-2020, including a stakeholder workshop and the authorship of a white policy paper on this topic. Our key research question is: what does the national government of the Netherlands need to do to address energy poverty in its energy transition policy? We ask this question in the context of the multi-level governance space for energy poverty policy in the Netherlands, which is shaped by municipal, regional and EU actors. To answer it, we bring to bear existing evidence on the national situation, theoretical insights from the governance literature, and inputs from an interdisciplinary stakeholder workshop on energy poverty in the Netherlands in 2019 (ENGAGER, 2019). We use these insights to identify a specific pathway to integrate the needs and concerns of the energy poor into a just energy transition in the Netherlands.

We begin by framing this work theoretically in the context of ideas and insights from (energy) governance literature, and outlining the method we used in researching this paper. We then document the current situation with regards to energy poverty in the Netherlands, including the state of the agenda, the state of the problem and the nature of energy governance in the Netherlands. We continue to show how the Climate Agreement (2019) necessitates a more thorough engagement with the energy poverty agenda at national level, presenting our proposal for integrating energy poverty into just transitions thinking in the Netherlands.

We conclude that engaging with the energy poverty agenda at national level is an opportunity to transform the Netherlands' planned low-carbon energy transition into a just transition. The multilevel governance space in which Dutch debates on energy poverty are currently taking shape, creates a promising context to address energy poverty through just energy transition policy. However, the current lack of a dedicated national framework hampers the effectiveness of local level initiatives, as well as risking the energy poor being left further behind in the energy transition. National energy transition policy must recognise energy poor households as needing additional support, engage them in policy design and monitoring, and ensure better outcomes for the energy poor in the short and long term. Here we demonstrate an alternative pathway to address energy poverty at the national policy level which could provide an inspirational example for other national governments that are trying to tackle energy poverty while simultaneously stimulating a low-carbon and just energy transition.

\section{GOVERNING THE JUST ENERGY TRANSITION; THE SPACE FOR ENERGY POVERTY}

The Dutch governance landscape, including as it applies to energy poverty policy and energy transition, can be characterised as a "multi-levelled governance" space whereby, first of all, each citizen is nested at the bottom of a "Russian Doll like" set of territorially-layered jurisdictions, of which each has its own set of governance functions and competences, and are in constant processes of negotiation, institutional creation and decisional reallocation (Hooghe and Marks, 2003; Jeffery and Peterson, 2020). In the Netherlands, citizens are governed by municipal governments, Provincial governments, national government, and the European Union, as the main supranational governance structure. This paper reflects on the interaction between these more "vertically-oriented" multi-levelled governance spaces for energy poverty and energy transition policy-making, also sometimes known as "multi-levelled government." Yet, we acknowledge in several places that "multi-level government" is equally increasingly understood as also involving various "intensified (horizontal) interactions between government and non-governmental actors" at each level, in addition to more specialised or sector-based governance (Bache et al., 2016).

Secondly, we think it is helpful to also make the connexion with energy justice debates, as an emerging framework in energy social science for the analysis of energy transitions and energy policy. The aim of energy justice is to contribute to a just energy transition through a just distribution of rights (distributive justice), recognition of needs (recognitional justice), and just decision-making within the energy system (procedural justice) (Sovacool et al., 2016). In this paper we consider how these dimensions contribute to the design of just energy transition policies, in the multi-levelled governance space of the Netherlands, though with a particular focus on the interaction between national, municipal and EU levels.

The Dutch energy poor are presently mostly "recognized" through the work of municipalities, whilst the EU is simultaneously legally obliging all national governments to render energy poor people visible throughout their territory by requiring all Member States to set criteria for defining energy poverty in the national context, taking into account 'necessary energy services for basic standards of living [see Governance Regulation on the Energy Union and Climate Action (EU) 2018/1999 and Electricity Directive (EU), 2019/944]. From a "(re)distributional" perspective, lacking attention to energy poverty nationally so far, seems worrying, since nearly all major decision-making and resource allocation for decarbonization and (just) transition currently stems from national law and policy mostly. The lack of a national programme and associated resources for proactively addressing (vulnerability to) energy poverty as the transition moves forward, might therefore seriously risk affecting the Dutch energy poor in the absence of limited alternative resources that could be harnessed either through the EU or municipalities (Straver et al., 2020).

\section{METHODS AND DATA}

The paper offers a commentary on the process by which policy and action on energy poverty in the Netherlands has developed in recent years. As such, it draws on a range of sources, including existing studies of energy poverty in the Netherlands, 
both qualitative and quantitative, and policy documents and communications on this topic in recent years, from the Dutch government and other actors in the Dutch energy transition. These studies and policy documents are referenced in parts 46 of this paper as appropriate, and are selected inclusively: we include all the studies that have been done on this topic, and all relevant policy texts. Further, the authorship team includes researchers that have been working on energy poverty for some years, and who are among the first to conduct research on this topic in the Netherlands. Some of the inputs below are therefore informed by an extensive engagement with this topic over time, and an associated deep familiarity with the subject matter. The authors represent a multidisciplinary background contributing legal expertise, gender analysis and stakeholder participation experiences.

Alongside these inputs, the authorship team ran a process of engagement with interdisciplinary stakeholders and academics, from the Netherlands and beyond in 2019-2020. The process and its outputs form part of the insights of this paper, and as such these deserve a more detailed description. The engagement process began with a multi-stakeholder, interdisciplinary and international workshop held in Amsterdam on the 30th and 31st of October 2019, funded and organised by the EU's COST Action ENGAGER-European Energy Poverty: Agenda Co-Creation and Knowledge Innovation (ENGAGER, 2019). The workshop brought together researchers, politicians, policymakers, energy companies and NGOs to discuss the state of energy poverty in the Netherlands, using lived experience examples to trigger thinking about potential for policy and practical solutions. During the workshop, clear challenges for addressing energy poverty in the Netherlands were identified, as well as possible solutions. The most apparent challenge was the lack of recognition of energy poverty at a national level, and the associated lack of national policy on this topic. This stimulated a small group of researchers and academics who were at the workshop to continue this engagement, working together to draught a White Paper on Energy Poverty (Straver et al., 2020).

To create the White Paper, we drew on a number of sources: the workshop experience, existing evidence on the national situation from sources described above, and empirical and theoretical insights from the international academic literature on this topic combined with lessons learned in other European nations. We are aware that each nation has its own political and socio-cultural context, which makes the adaptation of approaches to tackle energy poverty highly contextual. However, sharing our experience of intervening in the Netherlands to call for a national policy, and in particular in linking energy poverty and energy transition thinking, may prove useful for other nations that are designing energy poverty or energy transition policies.

\section{THE NETHERLANDS, ENERGY POVERTY AND THE ENERGY TRANSITION}

This section paints a picture of the state of play with regards to energy poverty in the Netherlands, outlining the energy poverty agenda and the experience of energy poverty in this country followed by a description of the governance context for energy transition and energy poverty.

\section{The Energy Transition Context of the Netherlands}

A defining feature of the Dutch energy transition is the phasing out of natural gas and its progressive substitution by less carbon-intensive heating alternatives, such as district heating and electricity. This "heating transition" is uniquely informed not only by national decarbonization targets, but also by major societal unrest arising in the recent years in response to severe damage caused by earth quakes and tremors to many homes across the Northern Province of Groningen due to prolonged natural gas extraction in the region. The Groningen gas field is Europe's largest natural gas field, and the main source for heating, hot water, and cooking for most Dutch households (72\% in 2016, CBS, 2018). In part due to the blocking of new extraction permits to the concession holders for the field, Exxon Mobile and Shell, as a result of successful lawsuits against the Government by citizens, interest groups, and local governments since 2014, the Government conceded in 2018 to phase out allnatural gas extraction from the Groningen field, first by 2030 and later by 2022 (Rijksoverheid, 2020). From a perspective of recognition justice, as well as the distribution of national rights and burdens, it is of particular interest how civil society and lower-level government successfully managed to invoke higherlevel human rights norms under the European Convention on Human Rights to change national natural resources policy.

It is uncertain how this rapid phasing out of natural gas consumption from the Groningen gas field might affect household energy prices over the coming years - the Netherlands became a net importer of natural gas for the first time in 2018, largely from Norway and Russia (PBL, 2018). Yet, the replacement of natural gas by electricity especially is presently running in parallel to significant changes in the relative prices of these two energy carriers in the household sector. Eurostat data indicate that electricity prices paid by the average Dutch household dropped from $17.67 \mathrm{c} € / \mathrm{kWh}$ in 2010 to 14.27 $c € /$ kWh in 2020 thus making the Netherlands one of the only three EU countries (along with Hungary and Malta) in which electricity prices went down in 2019-2020. This - 19\% decrease in the price of electricity over that 10 year period, comparing to an average increase of $+23 \%$ for the whole EU, resulted in the Netherlands reporting the lowest price of electricity per $\mathrm{kWh}^{1}$ in the EU as of the first semester of 2020 (Eurostat, 2021a). On the contrary, the price of natural gas went up by $46 \%$ between 2010 and 2020 (as compared to an 17\% increase as an average for the whole EU in the same period) and, as a result, in the year 2020 Dutch domestic consumers paid the second most expensive natural gas ${ }^{2}$ in the EU after Portugal (Eurostat, 2021b).

In the coming years, it is expected that the government will continue intervening in end-user prices of natural gas and

\footnotetext{
${ }^{1}$ Relative to general price and income levels of each EU Member State as measured by Eurostat's Purchasing Power Standard (PSS) units.

${ }^{2}$ As before, prices measured in Purchasing Power Standard (PSS) that account for differences in price and income levels of each country.
} 
electricity consumption via taxation to further reduce the weight of natural gas heating in the building sector (OIES, 2019). The government has already announced that taxes on natural gas consumption for households will be progressively raised over the coming years, while those on electricity will be lowered. Lastly, in the longer term, there are also major concerns and uncertainties about the household energy mix and the costs of the heating transition (Schellekens et al., 2019). The current household energy mix is natural gas (86\%) and electricity (14\%) for heating, cooking and hot water (PBL, 2018). The energy efficiency of residential buildings is low, with $61 \%$ having an energy efficiency label of $\mathrm{C}$ to $\mathrm{G}$ (ibid). Tenure data demonstrate that 6 out of 10 Dutch households are home-owners while 4 out of 10 are tenants (PBL, 2018).

\section{The National Energy Poverty Agenda in the Netherlands}

There is a limited understanding and recognition of energy poverty at the national government level, resulting in hardly a national policy interest in alleviating energy poverty. In contrast, Dutch national interest in a just transition is growing. A recent statement of the Ministry of Internal Affairs says that the energy transition needs to be "affordable and just" (Ministerie van Binnenlandse Zaken en Koninkrijksrelaties, 2020). In addition, the political opposition have filed several (narrowly rejected) motions in recent years, stating that the government should implement energy poverty alleviation measures. Despite these initiatives, Dutch national energy planning to date has done little to address the most vulnerable energy consumers. The Netherlands lacks a national definition or policies on energy poverty, rendering the interests of the energy poor invisible (Straver et al., 2020). The political position held by the central (liberal) government, is that alleviating energy poverty is a matter of mitigating poverty, and should be addressed through social welfare policy, not through energy policy. The lack of national policy on energy poverty is a barrier within the decentralised system, because without a national policy there are no centrally defined goals. Further, while decentralisation does enable tailormade policy interventions appropriate to specific contexts, it can also lead to inconsistency, under-provision of services or lack of control (de Jong and Vonk, 2019).

The government's National Climate and Energy Plan (NECP, 2019) follows this position by only reluctantly addressing the topic of energy poverty. After a reprimand of the Commission on this minimal reporting in the draught NECP, the final NECP acknowledges the various studies on Dutch energy poverty that have been published to date (discussed below, with emphasis on the PBL, 2018 study). It lists a set of general anti-poverty measures implemented by municipalities, but presents energy poverty as matter of general poverty alleviation via traditional social welfare action. In response, the European Commission finally concluded that the Netherlands has not yet addressed new EU legal requirements to properly set criteria for the definition and measurement of energy poverty (European Commission, 2019). In particular, the Commission's evaluation of the final NECP observed that the government made no mention of specific additional measures, but instead only refers to existing antipoverty policies that have been predominantly decentralised to municipalities.

\section{Measuring Energy Poverty in the Netherlands}

Research on energy poverty in the Netherlands is in its infancy. Initial quantitative work has mainly focused on measuring energy poverty in terms of the affordability of the energy bill (PBL, 2018; Schellekens et al., 2019). There has also been some qualitative lived experience research which has helped to add detail to our understanding of the daily lives of those facing a shortage of energy services (Woonbond, 2013, 2019; Straver et al., 2017), as well as a gender analysis of energy poverty in the Netherlands, which revealed a strong difference in energy poverty levels between women and men (Clancy et al., 2017). Further research combining mixed methods and comparative analysis would contribute to a deeper understanding of the experiences of energy poverty and provide data for the emerging policy agenda (ENGAGER, 2020b).

A challenge for furthering the Dutch debate on energy poverty, is that when energy poverty is measured through the headline indicators of the European Energy Poverty Observatory (EPOV), the Netherlands shows a low incidence compared to most other EU countries (EPOV, 2021). According to one of the most elaborate studies of energy poverty in the Netherlands by the Netherlands Environmental Assessment Agency PBL (PBL, 2018), a semi-public, but independent national institute for strategic policy analysis, and as subsequently confirmed in the Dutch NECP (2019), only $2.6 \%$ of Dutch respondents faced difficulties with affording adequate warmth in their home in 2016, while approximately $2 \%$ were in arrears on energy bills. These numbers are in line with the corresponding EPOV indicators that consistently show an incidence below 3\% for SILC indicators (inability to keep the home adequately warm and arrears on utility bills) since the mid-2000s (EPOV, 2021).

Yet, disaggregation of data seems key to properly recognising who is energy poor in the Netherlands. Just slightly scratching the surface of these national averages, reveals that difficulties with heating the home to be a problem for up to $16 \%$ for those living in social housing (free or regulated rent), whilst up to $7 \%$ of households in the lowest income deciles experienced arrears (EPOV, 2021). Similarly, the average share of the population meeting EPOV's high energy expenditure indicator seems low, compared to other EU countries-at about $11 \%$ of the population. Yet, this figure rises to $20-58 \%$ for the two lowest income deciles (EPOV, 2021).

Qualitative research reflected in the reports on expenditure on housing for households in the Netherlands (Woonbond, 2013 , 2019) shows that Dutch households facing energy poverty faced similar challenges to those in other nations. Households confronted by stressful living conditions (recent divorce, illness, care duties due to physical or mental illness of family members), were often unaware of or unable to care about energy use and energy bills. Owning used and energy inefficient appliances such as fridges or freezers, also created an energy poverty problem 
for households, but families lacked the means to invest in newer and more energy efficient appliances. People resort to coping strategies like heating restricted areas of the house-a phenomenon called spatial shrink. Some turn on their heating only for a limited number of hours each day, for example when (grand-)children are around. People also indicate waking or going to sleep several hours later or earlier than normally preferred, or limiting visits from family members. They are sometimes simply living in too cold, draughty, mouldy and unhealthy homes. This lived experience research by Woonbond, the association for housing, additionally showed the necessity to offer repeated energy saving advice, as households save more when they receive advice several times. Finding out about the intrinsic motivation of a household to save energy is an important aspect of motivating households to be aware of energy consumption in the long-term.

In addition, the PBL offered quantitative analysis of the affordability of energy bills in the Netherlands, using household energy expenditure, disposable income and other necessary expenditures, and measure affordability with two complementary indicators: the energy ratio and the payment risk. The "energy ratio"-also known as "energy burden" (Bouzarovski and Tirado Herrero, 2016)—is the share of disposable income that a household spends on energy. Following early fuel poverty measuring approaches developed in the UK, Dutch studies on the affordability of energy-have used an energy ratio of $10 \%$ (of a household's income spent on domestic energy) as a threshold to define energy poverty. In addition, the PBL (2018) considers that a household suffers a "payment risk" if after paying housing and energy costs their budget is insufficient to cover minimum subsistence expenditures. Using these two indicators, the number and percentage of households in energy poverty was estimated based on nationally available data on living costs (see Table 1). These figures suggest that up to $13.6 \%$ of Dutch households were experiencing financial difficulties related to energy poverty. A majority of those households were renting their dwelling and their income was below the median.

Shortcomings in the above calculations have been acknowledged. Many Dutch households struggling to afford the energy services are still unaccounted for in data, and thus invisible to policymakers and researchers. PBL (2018) indicates that their study could not account for a group of roughly 900,000 households (13\% of all Dutch households) which have

TABLE 1 | Households with high energy ratios and payment risk in The Netherlands (2014).

\begin{tabular}{lcc}
\hline & $\begin{array}{c}\text { Number of } \\
\text { households }\end{array}$ & $\begin{array}{c}\text { Percentage of } \\
\text { households }\end{array}$ \\
\hline $\begin{array}{l}\text { High energy ratio and } \\
\text { payment risk }\end{array}$ & 269,000 & $4.0 \%$ \\
High energy ratio only & 385,000 & $5.7 \%$ \\
Payment risks only & 259,000 & $3.8 \%$ \\
Any of the above & 913,000 & $13.6 \%$ \\
None of the above & $5,800,000$ & $86.5 \%$ \\
\hline
\end{tabular}

Based on: PBL (2018). circumstances that make it difficult to assess energy expenditure (e.g., students, entrepreneurs with a year of poor performance, households that share a residence, households with a business at home, or people living in unusual dwellings, such as houseboats or multi-occupancy dwellings). Evidence from other countries suggests that such groups also face difficulties with energy expenditure (Cauvain and Bouzarovski, 2016).

Furthermore, some households under-consume energy to save on energy expenditure hence their energy expenditureincome ratio might be under the $10 \%$ threshold because of their very low energy consumption. These households with underconsumption are not accounted for in Dutch quantitative studies, although a substantial portion of these households may be covered by PBL's category of households with a payment risk (PBL; Straver et al., 2017; Schellekens et al., 2019). According to the EPOV (2021), an average of $4.4 \%$ of the Dutch population had abnormally low energy expenditures (indicator $\mathrm{M} / 2$ : households whose absolute energy expenditure is below half the national median), amongst which between 5.5 and $10 \%$ of the lowest income deciles. These figures suggest under-consumption among energy poor households even if there is insufficient quantitative data on how low their energy use actually is.

Finally, another shortcoming in monitoring energy poverty is the lack of disaggregated data on household energy consumption, hiding the intersectionality of energy poverty amongst users and their consumption patterns. As discussed above, disaggregated data on energy poverty indicators for the Netherlands suggests that there is a higher incidence of energy poverty in social housing (reduced or free rent), amongst lower income groups, apartments, or in densely populated areas where the energy efficiency of residential buildings are low (Straver et al., 2020; EPOV, 2021). Importantly, households are fluid systems too: coparenting and multi-generational households are not reflected in the official data of household composition (Clancy et al., 2017). Better disaggregation on various household characteristics that are known to increase energy vulnerability is needed. This includes vulnerability based on gender, pensioners, children, migration background, disability, family size) (Clancy et al., 2017).

\section{Energy Governance in the Netherlands}

Although the Netherlands is geographically small, it is home to 17.5 million people that are governed through a fine-meshed network of governmental institutions and layers. This multilayered Dutch governance landscape is both a blessing and a curse for energy transition governance. The following sections narrow in on the role of different layers of government in shaping energy transition and energy poverty policy at the moment.

\section{National Governance}

The existing Dutch domestic decarbonisation policy framework is based on the Coalition Agreement after the 2017 elections (NECP, 2019). There is no mention of energy poverty in the national policy framework for energy transition, however it does create some opportunities for this agenda. The energy transition ambitions of the Dutch government are rooted in the Energy Agreement of 2013, and the Climate Agreement of 2019, and 
legally cemented through the Climate Act of May 2019. As already referred to in section The Energy Transition Context of the Netherlands, as part of the current Dutch Climate Agreement, the national government committed to the ambitious national objective of transitioning 1.5 million households of the 7.5 million Dutch households from natural gas to a different energy source for heating and cooking by 2030 (NECP, 2019). This will involve major infrastructural interventions in people's homes, such as the installation of new heating systems and retrofit measures in residential buildings, or the construction of district heating networks across Dutch municipalities.

In turn, commitments on decarbonization targets were shaped under influence of UN climate negotiations, EU climate law, as well as ground-breaking national climate litigation through the case of Urgenda vs. the Netherlands. In this case, civil society organisation Urgenda successfully legally challenged the adequacy of Dutch climate targets, based on the European Convention on Human Rights. Successive Dutch court judgments in 2015, 2018, and 2019 legally obliged the national government to mitigate GHG emissions by $25 \%$ by 2020 , a faster pace than the rate of 17-20\% mandated by the EU (NECP, 2019). These developments clearly reveal that energy transition policy and its agendas are well-established and shaped at national level, through multi-levelled processes / through interaction with civil society and supra-national governance processes.

\section{Lower-Level Governance}

Should we consider the national level a first layer of the national multi-levelled governance model of the Netherlands, then the 12 provinces present a second layer of the Dutch energy governance landscape. Each province has its own democratically elected government, and some of these have adopted regional energy poverty agenda's (Provinces of Utrecht, Zuid-Holland and the three Northern provinces Groningen, Friesland and Drenthe). These provinces are funding and stimulating research, provincial programmes and supporting municipalities in their projects and programs on energy poverty. The province of Utrecht has allocated a budget of $€ 8.9$ million on working towards a just energy transition, which includes financing and subsidising projects and renovation solutions for energy poor households.

The third level is the regional level. The Regional Energy Structures (RES) are a new energy governance arena, intended to reach decisions on decarbonisation options for 35 regions within the Netherlands. Each region has a target of renewable energy production for electricity, heat and infrastructure. Provincial and local government collaborate with companies, utilities and citizens to create regional choices on the decarbonisation of their region. Due to the lack of national policy combined with a lack of data on the phenomenon, RES plans do not currently address energy poverty. A local component of the RES consists of the municipal processes in developing Heat Transitions Visions at neighbourhood level, and the creation of timelines for this, through a similarly collaborative process at the local level.

Municipalities (the fourth level) are considered the directors of the heat energy transition in the Netherlands. The multilevel governance model of the Netherlands devolves much of the implementation of energy transition policy to municipalities, who are also responsible for implementation of social welfare policy (Straver et al., 2020). The 355 Dutch municipalities are presently granted a major executive and decision-making power in the implementation of the (heat) energy transition, especially through their work in developing Heating Transition Visions and setting the pace for neighbourhood-based heating solutions and timeframes. Some Heating Visions already published by several cities (Amsterdam, Amersfoort, Nijmegen) explicitly refer to addressing and preventing energy poverty as an integral concern to the transition. Concerning the integration of energy poverty in the local energy transition, the role of municipalities must be seen in the context of a wider decentralisation movement in the social domain that commenced in 2010. Through the so-called "Participation Law" of 2010, municipalities gained extensive devolved (implementation) responsibilities for decentralised social service provision, and poverty alleviation, including expectations of tailoring policy solutions to local households' needs (Dijkhof, 2014).

Through their engagement with socially vulnerable groups and poverty eradication activities, local authorities are acutely aware of the phenomenon of energy poverty (ENGAGER, 2019). Municipalities recognise the value of addressing multiple policy goals through energy poverty interventions, with a focus on stimulating energy efficiency to both reduce energy consumption for climate change and affordability reasons. However, local government efforts to address energy poverty are constrained by the absence of a national framework, lacking a clear mandate and adequate resources. Local government stakeholders advocate for national level policy instruments and a legal framework addressing energy poverty to support their work (ENGAGER, 2019).

\section{ENERGY POVERTY: A FAST RISING AGENDA IN THE NETHERLANDS}

The agenda of energy poverty is fast rising in the Netherlands. The devolved governance context has allowed the agenda of energy poverty to be taken up by municipalities and provinces, in innovative ways, bringing together climate change and poverty targets on the ground. At the same time, in parallel, the EU's demands for integrating energy poverty into transition planning are also placing pressure on the national government to act systematically on this agenda, alongside other international commitments.

\section{Innovative Action on Energy Poverty at Municipal and Regional Level}

Many municipal-level and local-scale energy poverty projects exist in The Netherlands, placing municipalities at the forefront of Dutch energy poverty policy making and demonstrating a strong bottom-up approach in agenda setting (Straver et al., 2020). Local governments have latched on to the energy poverty agenda as a fitting response to the challenges observed in their local communities that have the potential to be addressed by local action. Municipalities' decentralised responsibility for the implementation of social welfare is the reason that energy poverty 
amongst socially vulnerable groups came to light. In recent years, municipalities have also gained an important role in the implementation of central government's objectives on the energy transition, stimulating local (neighbourhood) approaches and solutions, though often with limited resources (Straver et al., 2020).

A large group of municipalities are actively developing strategies, action plans and regional agreements towards a just energy transition for all. For example, the municipality of Arnhem plans to implement a 3 year energy poverty program worth one million euro's which will benefit at least 2,500 energypoor households, and emphasises the benefits on welfare and health for energy poverty households. The Groningen City Council also reserved $€ 230,000$ annually for energy poverty alleviation in 2021-2024, following earlier ad hoc budgets of $€ 140,000$ and $€ 400,000$ in $2019-2021$. These activities are complemented by a $€ 1.4$ million subsidy provided by the national government to implement small energy efficiency improvements in homes ("low hanging fruit") to meet short-term energy transition targets. While the national government does not brand this subsidy as energy poverty-related specifically, the municipality has framed the support this way. The funding is so far spent on helping all households-not specifically targeted to vulnerable or energy poor ones-especially by deploying energy coaches (that provide free advice and insulation packages up to 60 euros). In 2021, the national subsidy was increased to 2 million. The Major of Groningen is also proposing a novel Energy Transition Fund, funded by revenues from exploiting renewable energy farms on municipal land, that can at least be partially targeted to tackling energy poverty.

\section{The Role of International Commitments in Raising the Agenda}

Aside from the bottom-up engagement on energy poverty in the Netherlands, also the EU has been progressively moving Member States to understand and address energy poverty since 2009 (Directive, 2009/72/EC). Recently it adopted legislation which now legally obliges all Members States to develop a "set of criteria" for defining energy poverty, and assess how many households are affected by it, taking into account "necessary energy services for basic standards of living" in the domestic context [(Regulation (EU), 2018/1999; Directive (EU), 2019/944); Commission Recommendation (EU) 2020/1563]. The same legislation also calls for EU Member States to develop national action plans aimed at decreasing the number of people suffering situations of energy poverty and to formulate a national indicative objective, along with a time frame, to eliminate energy poverty in case a "significant" number of households can be found to suffer from it. (Directive (EU), 2019/944) starts from the premise that any proportion of households in energy poverty can be considered to be significant.

Significantly, EU Governance Regulation on the Energy Union and Climate Action 2018/1999 requires all Member States to submit all their findings on energy poverty in the domestic context in NECPs in support of the EU's climate action and energy transition objectives (European Commission, 2018). This now effectively creates an obligation on the Netherlands to (a) define energy poverty, as demanded by EU law; (b) report and be transparent on it; (c) formulate objectives and policy to address it as necessary. Moreover, it creates a multi-levelled conversation between the European Commission and national government-upon which sub-national level actors might also act in terms of pointing out insufficient compliance of the Netherlands with EU law. Indeed, as pointed out by the European Commission, the requirements are not currently met by the Dutch government, but ultimately, the Netherlands and all other EU Member States cannot escape implementing and complying with legal requirements set out in EU regulations and directives.

In short, there is now an imperative to create national policy on this topic. Setting appropriate Dutch ambitions for the realisation of a just transition, must include national goals for mitigating household energy poverty and for ensuring equitable and affordable access to the "domestic energy services" as socially and materially necessary to guarantee basic standards of living, health, well-being and social inclusion (Directive (EU), 2019/944; Regulation (EU), 2018/1999; Bouzarovski and Petrova, 2015).

Finally, other Dutch international commitments beyond the EU are also critical here. Providing access to clean and affordable energy services for all citizens is a target the Dutch government is committed to through its support for the United Nations Sustainable Development Goals. Similarly, access to clean and affordable energy services is increasingly recognised as a human rights issue, for example through the EU Pillar of Social Rights, or through interpretation of the rights to adequate living standards, housing or health, protected by several international and European binding treaties that the Netherlands is a party to Hesselman (2021).

\section{AN INTERVENTION: PROPOSING A NATIONAL ENERGY POVERTY POLICY}

Having described the current energy poverty landscape in the Netherlands and explored the rise of the energy poverty agenda, in this section An Intervention: Proposing a National Energy Poverty Policy, we propose an intervention for integrating energy poverty in the energy transition. This proposal is built from the process of engagement we conducted between 2019 and 2020, and reflects the authors' understanding of the need for policy action, as well as the widespread consensus of the stakeholders attending the workshop we ran in 2019 on the need for a national energy poverty framework. It is also built on a deep understanding of the Dutch policy context, as well as state of the art academic understandings about the policy interventions to mitigate energy poverty.

The aim of the intervention is to propose an additional national policy in which energy poverty is integrated with the current energy transition policy. This would require government departments to work together towards goals for both policy agendas. It also would require a comprehensive national monitoring and measuring system for energy poverty. At present, understandings of the problem and its dimensions are vague, due to a lack of national measurement. 


\section{Integrating Energy Poverty and the Energy Transition}

Dutch Ministries have siloed goals and responsibilities and do not yet collaborate on the issue of addressing energy poverty. The Ministry for Economic Affairs and Climate Policy (EZ) is responsible for realising $\mathrm{CO}_{2}$ reduction targets, while the Ministry of the Interior and Kingdom Relations (BZK) is responsible for phasing out natural gas in the built environment, and the Ministry of Social Affairs and Employment (SZW) is concerned with social welfare and employment. When energy poverty is positioned as a social welfare problem, it falls clearly within the remit of SZW, but when it is more closely associated with the energy transition it belongs in EZ. This is a clear indication that collaboration between departments is essential to share budget, mandate and policy instruments to achieve a just energy transition in which energy poverty is eradicated (Clancy et al., 2017).

The lack of coordination between government departments is apparent in the current situation. Should SZW take on mitigating energy poverty, the emphasis might be on offering financial support and reducing energy prices. This, on its own, is not a sustainable solution, not least because research indicates that governments that focus only on lowering energy bills do not entirely solve the problem for the households facing energy poverty difficulties (Feenstra and Clancy, 2020). Further, lowering energy bills is a short-term measure that does not contribute to achieving decarbonisation targets in the long run. Investments in energy efficiency (of the household, or of appliances) are able to address both climate and energy poverty goals.

The Netherlands has a unique governance culture of "poldering" (striving for consensus), that paves the way for close cooperation between policy actors. We argue that there is much to gain from a more in-depth perspective on energy poverty combined with a more integrated approach of social policy, energy policy and urban planning. There are opportunities to address multiple challenges through energy poverty policy. Defining an energy poverty policy may give strategic direction to the way housing stock can be made sustainable, while setting up an energy poverty monitoring framework gives insight on who is vulnerable when it comes to energy use, and it contributes to monitoring current energy policy implementation. It enables energy retrofitting priorities to be established, focusing on the needs of the different household groups and accounting for their housing stock characteristics. This allows energy retrofitting policies to be assessed for their capability of tackling energy poverty.

\section{Measuring and Monitoring Energy Poverty Nationally}

Based on our research and insights gained from the stakeholder workshop, a recommendation is to implement a national measurement and monitoring system for energy poverty. There are plenty of experiences to draw on from other nations, and insights to use from academic research. Since this agenda emerged in the UK (Boardman, 1991), there have been prolonged debates about how best to measure energy poverty, which we will not revisit in detail here. A range of indicators can be found on the EU Energy Poverty Observatory (EPOV, see Bouzarovski and Thomson, 2019). Following the legislative mandate of (Regulation (EU), 2018/1999) and (Directive (EU), 2019/944) on common rules for the internal market for electricity, EU member states are putting in place quantitative measurement frameworks that contribute to better recognition of energy poverty by stakeholders and support targeted action (European Commission, 2018).

A recent example of the uptake of EU recommendations for the monitoring and reporting of energy poverty through indicators is the case of Spain. In this country, a growing societal and institutional recognition of energy poverty in the last decade has gone hand-in-hand with the publication of quantitative studies (e.g., Romero et al., 2014; Tirado Herrero, 2017; Tirado Herrero et al., 2018) that subsequently led to the adoption in 2019 of a specific national policy framework (the Spanish National Energy Poverty Strategy). The Spanish Strategy, which has an ambition to reduce the incidence of energy poverty by $25 \%$ between 2019 and 2024, has adopted almost unquestioningly the four headline indicators recommended by the European Energy Poverty Observatory (EPOV). According to the Spanish NECP, an annual update of those four indicators calculated in accordance to EPOV methodologies is published by mid-October every year by a public business entity (IDAE) attached to the State Secretariat for Energy.

The consensus is that energy poverty is a complex problem, and that it is measured best by using multiple indicators (Trinomics, 2016; Castaño-Rosa et al., 2019; ENGAGER, 2020a; Feenstra and Clancy, 2020; Straver et al., 2020). This allows capturing its complexity, and avoids the situation in which some experiences of energy poverty (e.g. spatial shrink, social isolation or household debt) are overshadowed by the aspects of domestic energy deprivation that are institutionally recognised and captured in indicators (e.g., energy bill cost, energy efficiency). Using a combination of indicators contributes to capture the diverse drivers and impacts of energy poverty, enables governments to design policy interventions that recognise and address the multi-dimensional nature of the problem.

In the case of the Netherlands, a monitoring framework sensitive to national conditions and capable of accounting for the multiple dimensions and experiences of energy poverty in the Dutch context should incorporate metrics beyond the ones already reported in the quantitative studies presented in section The National Energy Poverty Agenda in the Netherlands. Such a proposal, laid out in our White Paper as well (Straver et al., 2020), would include, for instance, indicators on household indebtedness to energy providers, dependency on social services for the payment of utility bills or difficulties in moving up the energy efficiency label ladder, or from natural gas-based to alternative heating systems as prescribed by Dutch energy transition guidelines. In addition, 
available data on energy poverty in the Netherlands so far, suggests it is imperative to collect disaggregated data too, for certain groups will be certainly more widely or deeply affected.

A call for mixed methods in energy poverty measuring and monitoring is also emerging, including the Netherlands (PBL, 2018; ENGAGER, 2020b; Straver et al., 2020). This builds on academic and policy work on the lived experience, which offers new and important insights into this complex topic (e.g., Middlemiss and Gillard, 2015; Middlemiss et al., 2018). Lived experience research uses qualitative methods to document people's lives in the face of reduced access to energy services. It offers insights into how people learn to cope with reduced access to energy services, what kinds of trade-offs they make, how different policies impact their lives and how their experience is affected by intersecting challenges. Qualitative monitoring methods using data based on the lived experience of the energy poor can provide useful insights into the impact of energy poverty policy on the energy poor. Furthermore, qualitative monitoring methods could reveal how the implementation of energy poverty policy is affected by a range of other policies that it intersects with, such as social welfare policy (ENGAGER, 2020b).

Equally, the lived experience is an opportunity to involve the energy poor in policy design. This can include talking to people experiencing energy poverty about specific policies before implementation as is being done in Scotland (Ipsos MORI Scotland, 2020). Given the devolved nature of Dutch governance, and the growth of this agenda from the bottom up (municipality/regional governance) in the Netherlands, the value of monitoring in the lived experience would be particularly high in the Netherlands. Insights from qualitative panel studies, with a cohort of households selected for diversity, and studied over time, would be hugely useful, in a context in which much of the decisionmaking power is held at local levels. There may also be the possibility to use such work as a means of monitoring poverty more generally-to share the costs of such monitoring between departments.

\section{CONCLUSION}

The last decade has seen a surge in energy poverty policymaking in the EU following its increased recognition as an issue on its own right different from-even if closely related to-other forms of monetary and material deprivation. In this process some Member States (e.g., Spain) have willingly followed the European Commission directions and are putting in place specific national monitoring and policy action frameworks aimed at quantifying and reducing the incidence of energy poverty. A risk of such dedicated efforts is, however, the creation of a new (energy poverty) policy silo lacking integration with pre-existing energy, climate and social policies. Other EU nations, on the contrary, reluctantly agree with EU recommendations and disregard or superficially treat energy poverty within key strategic documents such as National Energy and Climate Plans (NECPs). In the case of Northern and Western European Member States such as Germany, Denmark, Sweden, objectively low incidence rates have motivated their national governments to consider energy poverty within general income-related poverty thus advocating for traditional social welfare approaches for its alleviation (Bouzarovski et al., 2021).

While we are critical of such stances, our analysis of the Dutch case suggests that an initial resistance to openly accept energy poverty as a distinct challenge may effectively create opportunities for its integration with more prominent policy developments relevant to specific national contexts. In the Netherlands, the adoption of ambitious GHG emission mitigation targets, the Urgenda court case and the Groningen gas field earthquakes make energy transitions appear as a more compelling, salient issue in political and policy discussions. As argued in our White Paper (Straver et al., 2020), we see a window of opportunity to plug energy poverty into just energy transitions policy developments once the Dutch policymaking process realises that a significant fraction of households in the Netherlands, many of whom are experiencing energy vulnerability to some degree, face difficulties in moving from gas-based to alternative heating and, more generally, risk being harmed or "left behind" by the transition. Such developments have triggered an incipient discussion around energy poverty in the House of Representatives of the Netherlands and may lead the way to proper institutional recognition of the issue in the future.

With regards this last point, The Netherlands is a country with a rich legacy as a social welfare state. The national government wrongly assumes that energy poverty is tackled through existing social welfare policies. This situation is not unique to the Netherlands. Energy poverty is also overlooked in other countries with extensive social welfare policies, in which national governments believe that energy poverty will be dealt with through existing poverty eradication policies (see for e.g., Großmann and Kahlheber, 2017 on Germany). Addressing energy poverty can be politically sensitive since it can be seen as a failure of the welfare state to fulfil its function. However, as demonstrated above, energy poverty is still very much a challenge in the Netherlands, with many households unable to afford the energy services they need to live comfortably at home. In a sense, the framing of this problem as "energy poverty" is less acceptable in the Netherlands as a result of the common feeling that the welfare state is looking after people adequately, whilst moreover, energy consumption is still largely seen as a space of the free market.

Part of our approach in our white paper and indeed in this paper, was to clearly frame the problem of energy poverty through the just transition, which is a much more acceptable policy framing in the Netherlands. In a governance culture which values planning for the future, it makes sense to frame energy poverty problems as requiring better integration into future plans. Integrating knowledge of energy poverty into the just energy transition agenda creates a window of opportunity to raise this important challenge politically in the Netherlands. Perhaps this can also inspire those interested in raising the energy poverty agenda in other nations to find alternative routes to address this issue. 


\section{DATA AVAILABILITY STATEMENT}

The original contributions presented in the study are included in the article/supplementary materials, further inquiries can be directed to the corresponding author/s.

\section{AUTHOR CONTRIBUTIONS}

MF: conceptualisation, formal analysis, project administration, writing-original draft, and writing-review and editing. STH, $\mathrm{KS}$, and MH: validation, visualisation, writing-original draft, and writing-review and editing. LM: conceptualisation, formal analysis, writing-original draft, and writing-review and editing. All authors contributed to the article and approved the submitted version.

\section{REFERENCES}

Bache, I., Bartle, I., and Flinders, M. (2016). "Multilevel governance," in Handbook on Theories of Governance, eds C. Ansell and J. Torfing (Cheltenham, PA; Northampton, MA: Edward Elgar), 486-498.

Boardman, B. (1991). Fuel Poverty: From Cold Homes to Affordable Warmth. London: Belhaven Press.

Bouzarovski, S., and Petrova, S. (2015). A global perspective on domestic energy deprivation: overcoming the energy poverty-fuel poverty binary. Energy Res. Soc. Sci. 10, 31-40. doi: 10.1016/j.erss.2015. 06.007

Bouzarovski, S., and Thomson, H. (2019). Transforming Energy Poverty Policies in the European Union: Second Annual Report of the European Union Energy Poverty Observatory. EU Energy Poverty Observatory.

Bouzarovski, S., Thomson, H., and Cornelis, M. (2021). Confronting energy poverty in Europe: a research and policy agenda. Energies 14:858. doi: $10.3390 /$ en 14040858

Bouzarovski, S., and Tirado Herrero, S. (2016). Geographies of injustice: the socio-spatial determinants of energy poverty in Poland, the Czech Republic and Hungary. Post Communist Econ. 29, 1-24. doi: 10.1080/14631377.2016.12 42257

Castaño-Rosa, R., Solís-Guzmán, J., Rubio-Bellido, C., and Marrero, M. (2019). Towards a multiple-indicator approach to energy poverty in the European Union: a review. Energy Build 193, 36-48. doi: 10.1016/j.enbuild.2019. 03.039

Cauvain, J., and Bouzarovski, S. (2016). Energy vulnerability in multiple occupancy housing: a problem that policy forgot. People Place Policy 10, 88-106. doi: $10.3351 /$ ppp.0010.0001.0007

CBS (2018). Energieverbruik van Particuliere Huishoudens. Available online at: https://www.cbs.nl/nl-nl/achtergrond/2018/14/energieverbruik-vanparticuliere-huishoudens (accessed April 22, 2021).

Clancy, J., Daskalova, V., Feenstra, M., Franceschelli, N., and Sanz, M. (2017). Gender Perspective on Access to Energy in the EU. Study for the FEMM Committee of the EU Parliament. PE 596.816, Brussels.

de Jong, F., and Vonk, G. (2019). Internal coordination of social security in the Netherlands. Eur. J. Soc. Secur. 21:2. doi: 10.1177/13882627198 44985

Dijkhof, T. (2014). The Dutch Social Support Act in the shadow of the decentralization dream. J. Soc. Welfare Fam. Law 36, 276-294. doi: 10.1080/09649069.2014.933590

Directive (EU) 2019/944 of European Parliament and of the Council of 5 June 2019 on common rules for the internal market for electricity and amending Directive 2012/27/EU [2019], OJ L 158/125.

Directive 2009/72/EC of the European Parliament and of the Council of 13 July 2009 concerning common rules for the internal market in electricity and repealing Directive 2003/54/EC [2009], OJ L 211/55.

\section{FUNDING}

This article is based upon work from COST Action European Energy Poverty: Agenda Co-Creation and Knowledge Innovation (ENGAGER 2017-2021, CA16232) supported by COST (European Cooperation in Science and Technology - www. cost.eu). Support for MF's contribution was provided by funding from the Rijksdienst voor Ondernemend Nederland under the project User-Centred Energy Systems Technology Collaboration Programme by International Energy Agency Hard-to-Reach Energy Users Annex. Support for STH's engagement on the paper was provided by funding from the European Union's Horizon 2020 research and innovation programme under the Marie Skłodowska-Curie grant agreement No. 752870 (TRANSFAIR) and grant agreement No. 847052 (EmpowerMed).

ENGAGER (2019). Workshop Summary Amsterdam 30-31 October 2019. Making the Most of Qualitative Evidence for Energy Poverty Mitigation: A Research Agenda and Call for Action. Available online at: http://www.engager-energy. net/wp-content/uploads/2020/01/Amsterdam.pdf

ENGAGER (2020a). Compendium: On Existing and Missing Links Between Energy Poverty and Other Scholarly Debates, eds A. Stojilovska, et al. Available online at: http://www.engager-energy.net/wp-content/uploads/2020/ 04/COST_ENGAGER_WG4_Case_Study_Linking_debates_3-April-2020.pdf

ENGAGER (2020b). Making the Most of Qualitative Evidence for Energy Poverty Mitigation: A Research Agenda and Call for Action. eds L. Middlemiss et al. Available online at: http://www.engager-energy.net/wp-content/uploads/2020/ 02/ENGAGER-Policy-Brief-No.-3-February-2020-Making-the-Most-ofQualitative-Data-for-EP-Research-and-Action.pdf

EPOV (2021). High Share of Energy Expenditure Income (2M). Available online at: https://www.energypoverty.eu/indicator?primaryId=1460andtype= barandfrom $=2015$ andto $=2015$ and countries $=$ NLanddisaggregation $=$ none (accessed March 30, 2021).

European Commission (2018). Electricity Directive. Available online at: https://eur-lex.europa.eu/legal-content/EN/TXT/PDF/?uri=CELEX: 32018R1999andfrom $=\mathrm{EN}$

European Commission (2019) The European Green Deal. COM (2019) 640 Final. Brussels.

Eurostat (2021a). Electricity Prices for Household Consumers - Bi-annual Data (from 2007 Onwards) [nrg_pc_204]. Available online at: https://ec.europa.eu/ eurostat/web/products-datasets/-/nrg_pc_204 (accessed April 5, 2021).

Eurostat (2021b). Gas Prices for Household Consumers - Bi-annual Data (from 2007 Onwards) [nrg_pc_202]. Available online at: https://ec.europa.eu/eurostat/web/ products-datasets/-/nrg_pc_202 (accessed April 5, 2021).

Feenstra, M., and Clancy, J. (2020). "A view from the North: gender and energy poverty in the European Union," in Engendering the Energy Transition, eds J. Clancy, G. Özerol, N. Mohlakoana, M. Feenstra, and L. Sol Cueva (Cham: Palgrave Macmillan).

Großmann, K., and Kahlheber, A. (2017). "Energy poverty in an intersectional perspective: on multiple deprivation, discriminatory systems, and the effects of policies," in Energy Poverty and Vulnerability, eds N. Simcock, H. Thomson, S. Petrova, and a S. Bouzarovski (London: Routledge), 30-50.

Hesselman, M. (2021). "Energy poverty and household access to energy services in international, regional and national law," in Encyclopedia on Energy Law and the Environment, eds M. Roggenkamp, K. de Graaf, and R. Fleming (Cheltenham: Edward Elgar), 695-705.

Hooghe, L., and Marks, G. (2003). Unraveling the central state, but how? Types of multi-level governance. Am. Political Sci. Rev. 97, 233-243 doi: $10.1017 /$ S0003055403000649

Ipsos MORI Scotland (2020). Research Into the Lived Experience of Fuel Poverty in Scotland. Available online at: https:/www.gov.scot/publications/ research-lived-experience-fuel-poverty-scotland/) (accessed March 30, 2021). 
Jeffery, C., and Peterson, J. (2020). Breakthrough' political science: multi-level governance - reconceptualising Europe's modernised polity. Br. J. Politics Int. Relat. 22, 753-766. doi: 10.1177/1369148120959588

Middlemiss, L., and Gillard, R. (2015). Fuel poverty from the bottom-up: characterising household energy vulnerability through the lived experience of the fuel poor. Energy Res. Soc. Sci. 6, 146-154. doi: 10.1016/j.erss.2015. 02.001

Middlemiss, L., Gillard, R., Pellicer, V., and Straver, K. (2018). "Plugging the gap between energy policy and the lived experience of energy poverty: five principles for a multi-disciplinary approach," in Advancing Energy Policy: Lessons on the Integration of Social Science and Humanities, eds C. Foulds and R. Robison (Bern: Springer). p. 15-29.

Ministerie van Binnenlandse Zaken en Koninkrijksrelaties (2020). Kamerbrief Kostenberekening Klimaatakkoord Gebouwde Omgeving en Beantwoording Kamervragen. Kamerstuk: Kamerbrief 19 februari 2020. Available online at: https://www.rijksoverheid.nl /documenten/kamerstukken/2020/02/19/kamerbrief-kostenberekeningklimaatakkoord-gebouwde-omgeving-en-beantwoording-kamervragen (accessed March 30, 2021).

NECP (2019) Integrated National Energy and Climate Plan 2021-2030. Ministry of Economic Affairs and Climate Policy, Netherlands.

OIES (2019). The Great Dutch gas Transition. The Oxford Institute for Energy Studies, University of Oxford. Available online at: https://www.oxfordenergy. org/wpcms/wp-content/uploads/2019/07/The-great-Dutch-gas-transition-54. pdf

PBL (2018). "Meten met twee maten," in Een Studie Naar de Betaalbaarheid van de Energierekening van Huishoudens, eds M. Middelkoop, S. Van Polen, R. Holtkamp, and F. Bonnerman (Den Haag).

Regulation (EU) 2018/1999 of the European Parliament and of the Council of 11 December 2018 on the Governance of the Energy Union and Climate Action [2018], OJ L 328/1.

Rijksoverheid (2020). Definitief Einde Gaswinning Groningen Wettelijk Geregeld. Available online at: https://www.rijksoverheid.nl/actueel/nieuws/2020/11/24/ definitief-einde-gaswinning-groningen-wettelijk-geregeld (accessed April 22, 2021).

Romero, J. C., Linares, P., López Otero, X., Labandeira, X., and Pérez Alonso, A. (2014). Pobreza Energética en España. Análisis Económico y Propuestas de Actuación. Madrid: Economics for Energy.

Schellekens, J., Oei, A., and Haffner, R. (2019). De Financiële Gevolgen van de Warmtetransitie. Een Onderzoek Naar de Investeringsuitdaging,
Effecten op Energie-Betaalbaarheid en het Potentieel van (nieuwe) financieringsvormen. Ecorys.

Sovacool, B., Heffron, R. J., McCauley, D., and Goldthau, A. (2016). Energy decisions reframed as justice and ethical concerns. Nat. Energy 1:16024. doi: 10.1038/nenergy.2016.24

Straver, K., Mulder, P., Hesselman, M., Tirado Herrero, S., Middlemiss, L., and Feenstra, M. (2020). Energy Poverty and the Energy Transition. TNO. Available online at: https://www.tno.nl/en/about-tno/news/2020/11/energypoverty-and-the-energy-transition/?utm_medium =socialandutm_source $=$ linkedinandutm_campaign=reach-tno-systeemintegratie- 2020

Straver, K., Siebinga, A., Mastop, J., Van Lidth-de Jeude, M., Vethman, P., and Uyterlinde, M. (2017). Rapportage Energiearmoede. Effectieve Interventies om energie efficiëntie te Vergroten en Energiearmoede te Verlagen. ECN-E-17002. TNO-ECN. Amsterdam.

Tirado Herrero, S. (2017). Energy poverty indicators: a critical review of methods. Indoor Built Environ. 26, 1018-1031. doi: 10.1177/1420326X177 18054

Tirado Herrero, S., Jiménez Meneses, L., López Fernández, J. L., and Irigoyen Hidalgo, V. (2018). Pobreza Energética en España 2018. Hacia un Sistema de Indicadores y una Estrategia de Actuación Estatales. Madrid: Asociación de Ciencias Ambientales.

Trinomics (2016). Selecting Indicators to Measure Energy Poverty. Available online at: https://ec.europa.eu/energy/en/studies/selecting-indicators-measureenergy-poverty

Woonbond (2013). Rapportage Woonlasten Onderzoek. Lefier.

Woonbond (2019). Rapportage Meldpunt Energiealarm. Available online at: https://www.woonbond.nl/sites/woonbond/files/publicaties/Rapportage_ Energiealarm.pdf

Conflict of Interest: The authors declare that the research was conducted in the absence of any commercial or financial relationships that could be construed as a potential conflict of interest.

Copyright (c) 2021 Feenstra, Middlemiss, Hesselman, Straver and Tirado Herrero. This is an open-access article distributed under the terms of the Creative Commons Attribution License (CC BY). The use, distribution or reproduction in other forums is permitted, provided the original author(s) and the copyright owner(s) are credited and that the original publication in this journal is cited, in accordance with accepted academic practice. No use, distribution or reproduction is permitted which does not comply with these terms. 